\title{
Peningkatan Hasil Belajar Siswa Menggunakan Model Cooperative Learning Tipe Numbered Head Together (NHT) Dalam Bidang Studi Ilmu Pengetahuan Sosial
}

\begin{abstract}
Abstrak
Penelitian ini dilatarbelakangi penggunaan model pembelajaran yang kurang bervariasi. Model pembelajaran yang digunakan lebih banyak mengaktifkan guru daripada siswa. Hal ini terlihat dari kegiatan pembelajaran yang dilaksanakan, dimana guru lebih banyak berceramah dan bertanyajawab dengan siswa. Sehingga hasil belajar IPS siswa kelas VI rendah. Rumusan permasalahan dalam penelitian ini adalah bagaimana proses pelaksanaan pembelajaran dengan menggunakan model Cooperative Learning Tipe Numbered Head Together (NHT) untuk dapat meningkatkan hasil belajar siswa dalam bidang studi Ilmu Pengetahuan Sosial Kelas (IPS) kelas VI di SDN 08 Nan Sabaris? Hasil analisis data diperoleh keberhasilan aktivitas belajar pada siklus I meningkat dan hasil belajar siswa pada siklus I rata-rata mencapai $68,20 \%$, dan pada siklus II; sebesar $84,15 \%$. Jadi menunjukkan ada peningkatan pembelajaran siswa dari siklus I sampai siklus II. Dengan menggunakan model Cooperative Learning Tipe Numbered Head Together (NHT) dapat meningkatkan pemahaman materi membandingkan kenampakan alam dan keadaan sosial negara-negara tetangga. Kerja sama siswa dalam menyelesaikan tugas secara berkelompok juga meningkat, terbukti semakin aktifnya siswa belajar dan bertanyajawab memecahkan masalah dalam kelompok dan kemampuan mengerjakan tugas kelompok semakin cepat dan sempurna.
\end{abstract}

Kata Kunci: Hasil Belajar, Model Cooperative Learning Tipe Numbered Head Together (NHT), Ilmu Pengetahuan Sosial

\section{PENDAHULUAN}

Proses pembelajaran dilaksanakan untuk membantu siswa mencapai tujuan pendidikan. Tujuan pendidikan pada dasarnya adalah mengantarkan siswa ke arah perubahan tingkah laku, intelektual, moral maupun sosial agar dapat hidup mandiri sebagai individu dan makhluk sosial. Oleh karena itu, perlu kita sadari bahwa proses pembelajaran merupakan bagian yang sangat penting dari pendidikan.

Pembelajaran yang dilaksanakan secara berkualitas akan meningkatkan hasil belajar menjadi lebih baik. Guru memiliki peran yang sangat besar dalam mengorganisasi ruang belajar, siswa dan proses pembelajaran. Iklim pembelajaran yang dikembangkan oleh guru mempunyai pengaruh yang sangat besar terhadap keberhasilan dan kegairahan belajar. Selain itu, kualitas dan keberhasilan pembelajaran juga sangat dipengaruhi oleh kemampuan dan ketepatan guru dalam memilih dan menggunakan model pembelajaran. Sesuai dengan pendapat Arief (2005: 2) yang menyatakan "Pemilihan model dan metode pembelajaran yang sesuai dengan tujuan kurikulum dan potensi siswa merupakan kemampuan dan keterampilan dasar yang harus dimiliki oleh seorang guru." Hal ini didasari oleh asumsi, bahwa ketepatan guru dalam memilih model dan metode pembelajaran akan berpengaruh terhadap keberhasilan siswa dalam belajar.

Hasil observasi dan pengalaman peneliti selama ini dalam melaksanakan pembelajaran, khususnya bidang studi Ilmu Pengetahuan Sosial (IPS) menemui berbagai masalah. Masalah tersebut seperti pembelajaran IPS menggunakan model belajar yang konvensional (metode ceramah). Menggunakan metode ceramah ini mengakibatkan siswa pasif dalam mempelajari materi. Selain itu siswa hanya menjadi objek dengan menerima materi dari guru. Guru tidak memfasilitasi siswa untuk memperkaya materi yang dipelajari. Hal ini kurang membantu siswa mengembangkan potensi yang dimilikinya. Pembelajaran yang dirancang dan 
dilaksanakan guru kurang merangsang siswa untuk bisa mandiri sehingga prestasi siswa kurang optimal. Permasalahan ini ditambah dengan hasil belajar siswa yang rendah.

Masalah yang disampaikan di atas disebabkan salah satunya oleh guru yang tidak menggunakan model pembelajaran yang tepat untuk dapat mengaktifkan siswa dalam belajar. Hal ini senada dengan pernyataan Etin (2005:3) "Kondisi pendidikan IPS saat ini adalah menggunakan model belajar konvensional (ceramah), sedangkan model Cooperative Learning belum dilaksanakan." Padahal model Cooperative Learning dapat mengaktifkan siswa dalam belajar dan berdiskusi. Model Cooperative Learning membantu siswa belajar dari siswa lainnya dan antar siswa saling membelajarkan. Cooperative Learning ini mampu merangsang dan menggugah potensi siswa secara optimal dalam suasana belajar pada kelompok-kelompok kecil yang terdiri dari 2 sampai 6 orang siswa. Pada saat siswa belajar dalam kelompok akan berkembang suasana belajar yang terbuka dalam dimensi kesejawatan, karena pada saat itu akan terjadi proses belajar kolaboratif dalam hubungan pribadi yang saling membutuhkan. Pada saat itu juga siswa yang belajar dalam kelompok kecil akan tumbuh dan berkembang pola belajar tutor sebaya (peer group) dan belajar secara bekerja sama (cooperative). Salah satu tipe model Cooperative Learning adalah Numbered Head Together (NHT)

Berdasarkan permasalahan di atas, maka perlu diteliti lebih jauh tentang penggunaan Model Cooperative Learning Tipe Numbered Head Together (NHT) untuk meningkatkan hasil belajar siswa. Rumusan permasalahan penelitian ini adalah Bagaimana proses pelaksanaan pembelajaran dengan menggunakan model Cooperative Learning Tipe Numbered Head Together (NHT) untuk dapat meningkatkan hasil belajar siswa dalam bidang studi Ilmu Pengetahuan Sosial Kelas (IPS) kelas VI di SDN 08 Nan Sabaris?

\section{METODOLOGI PENELITIAN}

Penelitian ini menggunakan metode PTK (Classroom Action Research). PTK merupakan bentuk penelitian yang bersifat reflektif dengan melakukan atau meningkatkan praktek pembelajaran di kelas secara lebih profesional. Subjek penelitian ini adalah siswa kelas VI di SDN 08 Nan Sabaris yang berjumlah 25 orang, dimana siswa perempuan 9 orang dan laki-laki sebanyak 16 orang. Kegiatan penelitian ini terdiri dari kegiatan prapenelitian, pelaksanaan penelitian, dan kegiatan pasca penelitian. Kegiatan penelitian meliputi perencanaan, pelaksanaan, observasi, dan refleksi. Penelitian ini terdiri dari 2 siklus. Siklus pertama 3 kali pertemuan dan siklus kedua 2 kali pertemuan.

\section{Tahap Perencanaan}

1. Menyusun rancangan tindakan berupa model rencana pelaksanaan pembelajaran, hal ini meliputi:

a) Menyusun tujuan pembelajaran.

b) Memilih dan menetapkan materi.

c) Menyusun kegiatan belajar dan mengajar.

d) Memilih dan menetapkan media dan sumber belajar.

e) Menyusun evaluasi.

2. Menyusun indikator, deskriptor dan kriteria pembelajaran membandingkan kenampakan alam dan keadaan sosial negara-negara tetangga

3. Menyusun lembaran observasi untuk pengamatan

\section{Tahap Pelaksanaan Tindakan}

1. Peneliti melaksanakan pembelajaran membandingkan kenampakan alam dan keadaan sosial negara-negara tetangga sesuai rancangan yang dibuat.

2. Pengamat melakukan pengamatan dengan menggunakan format observasi, format pencatatan lapangan, dan alat perekam.

3. Peneliti melakukan diskusi terhadap tindakan yang dilakukan, kemudian melakukan refleksi, yang hasilnya nanti akan dimanfaatkan untuk perbaikan atau penyempurnaan pada siklus berikutnya.

\section{Tahap Pengamatan (Observasi)}

Dalam kegiatan ini peneliti dan pengamat berusaha mengenal, mendokumentasikan dan merekam semua kegiatan pembelajaran yang terjadi, baik yang disebabkan oleh tindakan terencana maupun dampak intervensi dalam pembelajaran tersebut. Dimana keseluruhan hasil pengamatan direkam dalam bentuk lembar 
observasi. Pengamatan dilakukan secara terus-menerus mulai dari siklus 1 sampai siklus 2. Hasil pengamatan ini kemudian didiskusikan dengan guru dan diadakan refleksi untuk perencanaan siklus berikutnya.

\section{Tahap Refleksi}

Refleksi diadakan setelah tindakan atau kegiatan pembelajaran berakhir. Dalam tahap ini pengamat dan peneliti mengadakan diskusi terhadap tindakan yang baru saja dilakukannya. Hal-hal yang dibicarakan dalam diskusi adalah sebagai berikut :

1) Menganalisis tindakan yang harus dilakukan.

2) Mengulas dan menjelaskan perbedaan rencana dan pelaksanaan tindakan yang telah dilakukan.

3) Melakukan intervensi, pemaknaan, dan penyimpulan data yang diperoleh.

Hasil dari refleksi ini dapat dimanfaatkan sebagai masukan dari tindakan selanjutnya, dan dapat digunakan untuk menyusun simpulan terhadap hasil dari siklus 1 dan siklus II.

\section{HASIL DAN PEMBAHASAN PENELITIAN}

Dalam pelaksanaan tindakan pembelajaran, peneliti bertindak sebagai guru sedangkan teman sejawat sebagai pengamat. Tahap-tahap pembelajaran setiap tindakan disesuaikan dengan tahap-tahap pembelajaran. Hasil Penelitian setiap siklus sebagai berikut:

\section{Hasil Penelitian Siklus I}

Penelitian dilakukan 3 kali pertemuan dengan kompetensi dasar yaitu membandingkan kenampakan alam dan keadaan sosial negara-negara tetangga. Pertemuan $1 \& 2$ hari Kamis, tanggal 9, 16 dan 23 September 2015 pukul 10.40 sampai 12.15 .

\section{Tahap Pelaksanaan}

Pelaksanaan siklus I ini berpedoman pada langkah-langkah Model Cooperative Learning tipe Numbered Head Together (NHT) yakni sebagai berikut: 1) Guru menyampaikan materi pembelajaran atau permasalahan kepada siswa sesuai kompetensi dasar yang akan dicapai. 2) Guru memberikan kuis secara individual kepada siswa untuk mendapatkan skor dasar atau awal. 3) Guru membagi kelas dalam beberapa kelompok, setiap kelompok terdiri dari 4-5 siswa, setiap anggota kelompok diberi nomor atau nama. 4) Guru mengajukan permasalahan untuk dipecahkan bersama dalam kelompok. 5) Guru mengecek pemahaman siswa dengan menyebut salah satu nomor (nama) anggota kelompok untuk menjawab. Jawaban salah satu siswa yang ditunjuk oleh guru merupakan wakil jawaban dari kelompok. 6) Guru memfasilitasi siswa dalam membuat rangkuman, mengarahkan, dan memberikan penegasan pada akhir pembelajaran. 7) Guru memberikan tes/kuis kepada siswa secara individual. 8) Guru memberi penghargaan pada kelompok melalui skor penghargaan berdasarkan perolehan nilai peningkatan hasil belajar individual dari skor dasar ke skor kuis berikutnya (terkini).

Jumlah keseluruhan nilai yang dapat dicapai oleh peserta didik pada siklus I ini adalah sebanyak 1705 dengan nilai rata-rata sebesar 68,20. Persentase ketuntasan yang tuntas sebesar 52,00\% dan yang tidak tuntas sebesar $48,00 \%$. Hal ini berarti taraf pencapaian hasil tes adalah sebesar $52,00 \%$. Nilai yang diperoleh pada siklus I ini belum mencapai angka target pencapaian daya serap klasikal $(\mathrm{KKM}=75 \%)$, angka ini dinilai masih rendah.

\section{Pengamatan}

Mengamati jalannya pelaksanaan pembelajaran dengan menggunakan Model Cooperative Learning tipe Numbered Head Together pada siklus I. Dalam kegiatan ini peneliti berusaha mengenal dan mendokumentasikan semua indikator dari proses hasil pembelajaran dengan menggunakan Model Cooperative Learning tipe Numbered Head Together ini dalam lembar observasi guru dan siswa.

Hasil pengamatan pada siklus I ini masih terlihat guru lebih dominan memberikan penjelasan materi. Saat guru memberikan kuis atau pertanyaan untuk individu siswa, belum terlihat semua siswa ikut berperan aktif. Hal ini terjadi karena guru belum dapat memotivasi siswa untuk menjawab pertanyaan. Saat kegiatan diskusi dalam kelompok, terlihat siswa tertentu yang aktif menjawab permasalahan yang 
diajukan guru. Guru kurang membimbing siswa dalam melakukan diskusi kelompok. Saat guru mengecek pemahaman siswa terhadap materi yang dipelajari, maka siswa yang aktif dalam kelompok yang dapat menjawab pertanyaan. Sehingga jawaban siswa tersebut tidak dapat mewakili pemahaman setiap anggota kelompok.

Pengamatan ini dilakukan secara berkelanjutan mulai dari tindakan awal pada pertemuan I sampai tindakan akhir pada petemuan II. Hal ini dikarenakan oleh pengamatan terhadap satu tindakan akan berpengaruh pada tindakan yang lainnya. Hasil pengamatan ini kemudian direfleksi untuk perencanaan pada siklus II.

\section{Refleksi}

Catatan hasil pengamatan terhadap pembelajaran IPS pada materi kenampakan alam dan keadaan sosial negara-negara tetangga yang dilakukan peserta didik melalui pembelajaran Model Cooperative Learning tipe Numbered Head Together ini merupakan dasar dalam melakukan refleksi. Hasil refleksi pada siklus I adalah :

a. Secara umum telah terjadi peningkatan hasil belajar membandingkan kenampakan alam dan keadaan sosial negara-negara tetangga melalui pembelajaran Model Cooperative Learning tipe Numbered Head Together ini dengan pemberian latihan secara pribadi, akan tetapi nilai hasil belajar membandingkan kenampakan alam dan keadaan sosial negara-negara tetangga masih rendah.

b. Masih terdapat kebiasaan peserta didik yang tidak aktif dalam melaksanakan tugas kelompok.

c. Saat diberi kuis secara individu, banyak siswa yang tidak mengerjakan latihannya sendiri dan menyalin hasil kerja temannya.

d. Siswa tidak percaya diri dalam menjawab pertanyaan guru. Banyak siswa yang meragukan jawabannya sendiri. Hal ini menyebabkan rendahnya nilai yang diperoleh peserta didik dalam belajar.

Untuk mengatasi masalah tersebut, maka perlu dilakukan perbaikan pembelajaran. Langkah-langkah perbaikan yang dilakukan sebagai berikut.

a. Guru menyampaikan materi pembelajaran atau permasalahan kepada siswa sesuai kompetensi dasar yang akan dicapai.

b. Guru memberikan kuis secara individual kepada siswa untuk mendapatkan skor dasar atau skor awal. yang berupa isian pendek sebanyak 10 buah soal yang memuat tentang membandingkan kenampakan alam dan keadaan sosial negara-negara tetangga.

c. Guru membagi kelas dalam beberapa kelompok, setiap kelompok terdiri atas 4-5 orang siswa, setiap anggota kelompok diberi nomor atau nama berbeda.

\section{Hasil Penelitian Siklus II}

Hasil analisis refleksi pada siklus I menunjukkan belum keseluruhan subjek penelitian mencapai tujuan pembelajaran khususnya yang diharapkan. Karena itu pembelajaran dilanjutkan dengan siklus II. Pembelajaran siklus II diberikan agar siswa dapat memahami lebih lanjut materi yang diberikan peneliti tentang membandingkan kenampakan alam dan keadaan sosial negara-negara tetangga. Pertemuan I - II hari Kamis, tanggal 8 dan 15 Oktober 2015 pukul 10.40 sampai 12.15.

\section{Tahap Pelaksanaan}

Pembelajaran siklus II berlangsung selama 105 menit. Dalam pelaksanaan siklus II ini peneliti tetap bertindak sebagai guru seperti dalam siklus I sedangkan guru kelas VI SDN 08 Nan Sabaris sebagai pengamat didampingi oleh seorang rekan sejawat. Penggunaan Model pembelajaran Cooperative Learning tipe Numbered Head Together ini dengan kegiatan peneliti menyampaikan materi tentang membandingkan kenampakan alam dan keadaan sosial negara-negara tetangga dengan memberi penjelasan sedikit tentang kenampakan alam di negara tetangga, serta dengan tanya jawab tentang materi tersebut. Peneliti kembali membagi siswa ke dalam kelompok baru yang berbeda kelompok waktu pada siklus I. Hal ini dilakukan karena dianggap siswa akan bosan dengan kelompok yang lama dibentuk berdasarkan skor akhir siklus I sebagai skor awal siklus II. 
Peneliti menugaskan siswa duduk dalam kelompok masing-masing. Permasalahan yang diajukan peneliti menyangkut kenampakkan alam negara tetangga dan mengingatkan agar siswa ikut aktif dalam diskusi, peneliti akan memilih siswa yang akan melaporkan dan mempresentasikan hasil diskusinya ke depan kelas. Sedangkan siswa lain menanggapi dan memeriksa hasil kelompoknya sendiri. Guru memberikan tes/kuis kepada siswa secara individual.

Jumlah keseluruhan nilai yang dapat dicapai peserta didik pada siklus II ini adalah sebanyak 2105 dengan nilai rata-rata sebesar 84,20. Hal ini menunjukkan taraf pencapaian hasil belajar pada siklus II yang diperoleh peserta didik adalah sebesar 92,00\%. Bila dibandingkan dengan angka target pencapaian daya serap klasikal $(\mathrm{KKM}=75 \%)$, angka ini dinilai telah melampaui target pencapaian daya serap klasikal.

\section{Pengamatan}

Hasil pengamatan pada siklus II ini sudah terlihat beberapa kegiatan yang sudah lebih baik. Guru lebih sedikit memberikan penjelasan terhadap materi yang dipelajari. Guru sudah membimbing siswa melakukan kegiatan diskusi. Guru membimbing siswa dengan berkeliling dari satu kelompok ke kelompok lain. Hal ini sangat membantu siswa yang belum aktif menjadi lebih aktif. Selain itu guru dapat memastikan bahwa setiap anggota dalam kelompok sudah memahami permasalahan yang didiskusikan. Saat melaporkan hasil diskusi di depan kelas, guru meminta siswa yang belum pernah berbicara ke depan kelas untuk melakukannya.

\section{Refleksi}

Setelah melakukan serangkaian kegiatan tindakan kelas maka refleksi dalam siklus II ditemukan bahwa :

1. Kegiatan diskusi dalam pembelajaran sudah berlangsung baik, karena siswa sudah bersedia untuk tampil ke depan kelas untuk melaporkan hasil diskusinya.

2. Kuis yang diberikan pada siklus II sudah dapat terselesaikan dengan baik oleh siswa terbukti dengan meningkatnya hasil belajar siswa.

\section{Pembahasan}

Pembelajaran dengan model cooperative learning merupakan pembelajaran yang membantu siswa belajar untuk bekerjasama dan saling membantu satu sama lainnya. Prinsip kerjasama mengharuskan masingmasing siswa memiliki peran dalam kelompoknya. Jika dapat saling bekerjasama, maka setiap siswa akan dapat mendukung semua kegiatan dalam pembelajaran. Pelaksanaan pembelajaran dengan model cooperative learning dapat berhasil jika guru dapat mengkondisikan siswa (1) saling membutuhkan satu dengan yang lainnya untuk menyelesaikan tugas, (2) bertanggungjawab menyelesaikan tugas tertentu dalam kelompoknya, (3) memiliki keterampilan personal (Mohamad Nur:2005; Jolliffe:2007:3). Pembelajaran dengan menggunakan model cooperative Learning tipe NHT merupakan sebuah grup diskusi yang mempengaruhi pola interaksi siswa yang dapat meningkatkan prestasi akademik (Kagan dalam Ibrahim :2000: 28) sangat membantu siswa untuk meningkatkan hasil belajarnya pada bidang studi IPS. Model pembelajaran cooperative learning tipe NHT memiliki kelebihan dan kekurangan.

Pembelajaran NHT terdiri dari beberapa langkah. Para ahli mengemukakan langkah-langkah pembelajaran NHT sebagai berikut.

1. Numbering, yaitu guru membagi kelas menjadi kelompok-kelompok kecil.

2. Guru mengajukan beberapa pertanyaan yang harus dijawab oleh tiap-tiap kelompok.

3. Kelompok berdiskusi menemukan jawaban. Pada kesempatan ini tiap-tiap kelompok berdiskusi memikirkan jawaban atas pertanyaan dari guru. Menyatukan kepalanya "heads together". Maksudnya menyatukan ide dari masing-masing anggota kelompok.

4. Guru memanggil peserta didik yang memiliki nomor yang sama tiaptiap kelompok. Mereka diberi kesempatan memberi jawaban atas pertanyaan yang telah diterimanya dari guru. Berdasarkan jawaban itu guru dapat mengembangkan diskusi lebih mendalam, sehingga peserta didik dapat menemukan jawaban pertanyaan itu sebagai pengetahuan yang utuh (Suprijono:2009: 92). 
5. Setiap model pembelajaran memiliki kelebihan dan kekurangan. Begitu juga pembelajaran model cooperative learning tipe NHT ini. Kelebihan cooperative learning tipe NHT sebagai berikut. a) Setiap siswa menjadi siap semua. b) Siswa dapat melakukan diskusi dengan sungguh-sungguh. c) Siswa yang pandai dapat mengajari siswa yang kurang pandai. Kelemahan model NHT, yaitu: a) Kemungkinan nomor yang dipanggil akan dipanggil lagi oleh guru. b) Tidak semua anggota kelompok dipanggil oleh guru (Hamdani: 2011: 90).

\section{KESIMPULAN DAN SARAN}

\section{Simpulan}

1. Pelaksanaan pembelajaran dengan menggunakan Model Cooperative Learning tipe Numbered Head Together ini sesuai dengan perencanaan yang dibuat mencakup keseluruhan langkah yang telah ditetapkan. Penggunaan Model Cooperative Learning tipe Numbered Head Together dapat membangkitkan keaktifan siswa dalam melakukan diskusi. Selain itu juga memberikan semangat untuk siswa agar mau mempresentasikan ke depan kelas. Melalui penggunaan mode Cooperative Learning tipe Numbered Head Together ini siswa sudah bisa memacu dirinya sendiri untuk ikut aktif dalam diskusi dengan dorongan semangat yang diberikan guru. Selain itu, dengan belajar dalam kelompok siswa dilatih untuk berbagi pengalaman, berani mengemukakan pendapat, serta mau menerima perbedaan pendapat yang terjadi antar kelompok.

2. Hasil belajar dengan menggunakan model Cooperative Learning tipe Numbered Head Together ini dapat meningkat dengan rata-rata skor awal (pre test) 40,90 setelah dilaksanakan tindakan rata-rata meningkat menjadi 68,20 atau persentasenya 52\% siswa yang tuntas pada siklus I demikian juga pada siklus II dengan rata-rata 84,20 atau persentasenya $92 \%$ siswa yang tuntas.

\section{Saran}

1. Agar guru menerapkan model Cooperative Learning tipe Numbered Head Together

2. Untuk Kepala sekolah, agar dapat berupaya meningkatkan sarana dan prasarana yang menunjang keberhasilan guru dalam meningkatkan hasil belajar siswa terutama dalam penggunaan model Cooperative Learning tipe Numbered Head Together.

3. Untuk teman sejawat dapat menambah wawasan tentang penggunaan model Cooperative Learning tipe Numbered head together dalam meningkatkan hasil belajar IPS siswa SD.

\section{DAFTAR PUSTAKA}

Arief. 2005. Implementasi Model Cooperative Learning Dalam Pendidikan IPS Di Tingkat Persekolahan 2005. (http://re-searchengines.com/0805arief6.html/05/02/2008/11:35)

Bulan Purnama. Penelitian Tindakan Kelas. (http://infopendidikankita. blogspot. com /2008/03/penelitiantindakan-kelas.html/18/03/2008/15:10)

Depdiknas. 2006. kurikulum Tingkat Satuan Pendidikan. Jakarta

Dewantari. 1999. Pengertian Ilmu Pengetahuan sosial. (http://www.blogger .com /feeds/3903308017353835410/posts/defaul/05/02/2008/10:13)

Etin Solihatin. 2005. Cooperative Learning Analisis Model Pembelajaran IPS. Jakarta:Bumi Aksara.

Hamdani. 2011. Strategi Belajar Mengajar. Bandung: CV Pustaka Setia.

Ibrahim, dkk,. 2000. Pembelajaran Kooperatif. Surabaya: Universitas Negeri Surabaya Press.

Jolliffe, Wendy. 2007. Cooperative Learning in the Classroom; Putting it into Practice. London: Paul Chapman Publishing.

Mohamad Nur. 2005. Pembelajaran Kooperatif. Jawa Timur: LPMP.

Nurhadi. 2003. Pembelajaran Kontekstual (Contextual Teaching and Learning/CTL) dan Penerapannnya Dalam KBK. Malang:Universitas Negeri Malang.

Nur Asma. 2006. Model Pembelajaran Kooperatif. Jakarta:Depdiknas

Rochiati Wiriaatmadja. 2007. Metode Penelitian Kelas. Bandung: Rosdakarya.

Slameto 1995. Hasil Belajar. (http://digilib.upi.edu/pasca/submitted/etd-0524107102147/unrestricted/BAB_1.pdf/08/04/2008/10:10)

Suprijono, Agus. 2009. Cooperative Learning Teori dan Aplikasi PAIKEM. Yogyakarta: Pustaka Pelajar.

Zulaini. 2005. Upaya Meningkatkan Kemampuan bicara Melalui Metode dan Media Yang Bervariasi. UNP:Padang. 